\title{
The Rate of Adoption of Strategic Marketing Planning (SMP) by the Libyan Commercial Banks (LCBs). An Exploratory Study
}

\author{
By Fthia Ramdan M. Abusafrita*
}

\begin{abstract}
The purpose of this paper is to explore the foundations of SMP process in the LCBs being adopted in 2007. An interpretive approach was chosen to address the research questions posed. In order to address the research objectives the survey strategy has chosen to answer the research questions. The triangulation of qualitative, quantitative techniques and archival data suggested by the interpretive philosophy and deductive approach is used for the reasons given above. The descriptive statistic analysis is used to analyse the structured questionnaires, and the pattern matching and coding analysis is utilised in order to analyse the semi-structured interviews. The major findings in this research are: comprehensive strategic plans are in place, but that the processes by which they are created have significant limitations. In addition, SMP in the LCBs is still evolving and that it is, currently, in growth. In terms of marketing lifecycle, marketing in LCBs is in its infancy stage, it was found, contrary to expectations that marketing departments have only been established recently. For this reason a number of barriers to SMP were found.
\end{abstract}

Keywords: Competitive strategies, Environmental change, Marketing capabilities.

\section{Introduction}

The results of Al-Shammari and Hussein (2007) study indicated that firms that implement strategic planning outperform those that do not. SMP is not the same as marketing planning. Marketing planning deals with marketing mix, whereas, SMP is about planning for all of an organisation's strategy and market place (Baker 2007). Brooksbank (1999) defends SMP as: "a management discipline which enables the firm to improve its competitiveness by becoming more responsive and adaptable to changing market conditions".

SMP can improve an organization's competitiveness by being responsive to the change in market conditions (Brooksbank 1999). There is a strong relationship between environmental change and strategic planning intensity, which means that, in order to cope with a changeable environment, the organization should use strategic planning (Miller and Friesen 1983, Ansoff 1991).

*Staff Member, Al Zawia University, Libya. 


\section{Research Questions}

The aim of creating enterprises is to achieve long- and short-term objectives (Bradmore 1996). To achieve these goals most organisations use strategic planning, which allows them to choose the appropriate strategy and manage their resources to achieve competitive advantage in their way of dealing with environmental changes (Moore 2001).

The main aim of this study is to answer the question of: why and how SMP should be adopted by LCBs? What is impact of contextual factors on the current state of development of SMP approach in the LCBs. Finally, what are the potential benefits of an enhanced rate of FSMP adoption and how might this be achieved.

\section{Research Objectives}

An organisation identifies its objectives in order to define itself in its environment and provide standards for measuring organisational performance (Coulthard et al. 1996). The current research aims to study, assess, and analyse SMP practice in the LCBs, to examine the effect of contextual factors (both internal and external) on the process of SMP, to investigate whether the SMP was/is managerially useful, and to provide a basic database for further research to examine the effect of SMP on performance in the LCBs.

\section{Literature Review}

\section{Marketing Strategy and Marketing Planning}

Marketing is precisely focused on what an organization wants to be by selling, advertising, and promoting. Marketing has a significant role for all organizational levels. For example, at the corporate level marketing influences the organizational culture, at the strategic business level marketing leads the organization to a competitive position and at the operational level marketing is responsible for developing the 5Ps mix (West et al. 2010).

In one hand, marketing strategy is the broad concept of how the 5Ps function as a co-ordinated way to meet marketing goals (O'Shaughnessy 1995). In addition, it is a plan which determines a firm's marketing aims; this usually includes product development; service quality; 5P strategies which include: promotions, producing, placing, people and a pricing strategy. Marketing strategy defines broad marketing activities for organizations, which takes a long time. In order to establish a competitive position, an organization has to respond to a changeable business environment. This requires analyzing, segmenting the market, evaluating the competitors' offers, and positioning products. As for tactical marketing, this concerns day-to-day marketing activities; it deals with marketing mix individually (Drummond et al. 2010). 
In other hand, marketing planning improves an organization's ability to cope with the complexities of the business environment (Dibb et al. 2001). McDonald (2007) remarked that marketing planning is a logical sequence and a series of activities leading to the setting of marketing objectives and the formulation of plans for achieving them.

The benefits of marketing planning are undefined and take place within the whole context of an organization. Marketing strategy helps organizations to be clear about what it is and where it is going. In other words, an organization with a marketing strategy implemented, better anticipates change and is less vulnerable to the unexpected. Furthermore, it has proactive responses to environmental changes which can minimize the random decisions that can take a business by surprise, and thus create better communication. Marketing planning also can create greater inter-functional co-ordination and achieve minimum waste and duplication of resources

\section{Marketing Department and Marketer Capabilities}

Specialization is a degree of distribution of the tasks and activities in the organization. There is a link between the existence of specialists in the organization and the degree of specialization within the organization (Olson et al. 2005).

Marketing managers can use three ways to facilitate marketing; the first is by educating the employees about marketing concept, purposes, and applications. The second is by using effective sales training programmes and sales tools, and finally, by pushing marketing responsibility downward into the company to be closer to client (Akroush 2003). Anderson (1982) asserted that marketing managers have the most significant role in providing strategic information and this is due to marketing managers "working towards satisfying long-term customer needs".

Day (1994) and Song et al. (2008) emphasise that the role of marketing capabilities is about achieving and sustaining competitive advantage. In service organizations, the marketing function is positively associated with marketers ${ }^{\text {* }}$ ability to deliver service to the customer (Moorman and Rust 1999). Therefore, staff need to be trained to deliver this level, and their performance should be monitored. In addition, marketing planners need to cover some areas, for instance, the perceptions and needs of customers, their willingness and ability to pay for this level; competitor approaches, the organization's ability to deliver this service at this level including the cost of delivering and the results to be gained in the short and long term (Wilson and Gilligan 1997).

\section{Strategic Marketing Planning (SMP)}

Strategic planning is a process of deciding an organization's mission, long and short-term objectives, strategies, tactics and resources; these enable organizations to achieve their goals. "SMP is a similar process but within the marketing function of the firm" (Claycomb et al. 2000). It is a plan of all 
aspects of an organization's strategy in the marketplace; it is concerned with long term issues (Baker 2007).

The main focus of SMP is to distinguish an organization from its competitors by using relative strengths to satisfy customer wishes (Claycomb et al. 2000). In other words, SMP is about deciding what marketing strategies should be used to obtain sustainable competitive advantage.

McDonald (1996) identified five potential benefits of using SMP: firstly, that it enables better coordination between employees working together, bringing together all relevant facts and operating decisions in order to better anticipate development, a more positive attitude towards change, better allocation of resources in sales promotion and finally setting up a framework which can better quantify marketing accomplishments. In general, SMP makes for better coordination of functions within the organization.

\section{Business Environment \& Competitive Strategies}

The aim of any organization is success, and understanding the environment is the most important stage of success. To achieve this aim an organisation must fit its strategy with its environment. Several authors have stressed this (Hussey 1985, McDaniel and Kolari 1987, McDonald 1989, Homburg et al. 2000).

They added that organizations use SMP to deal with increasing environmental turbulence, complexity, competitive pressures, the pace of technological change, organizational diversification and size, societal performance, demands on organizations, and more recently the disappearance of conventional marketing structures. Therefore, systematic scanning and analyzing macro/remote environment and micro/competitive environment is necessary (West et al. 2010).

SWOT analysis is defined as a systematic way for a company to assess its overall structure and involves internal and external analyses in order to match what the organization offers with the environment between what the environment can provide and what an organization needs (West et al. 2010). After that, marketers can set their marketing objectives, and develop their marketing plans which include implementing, monitoring and evaluating marketing plans (McGivern 2009).

In a changeable environment, one of the strategies that companies should focus on is the creation of cross-functional committees (Calantone et al. 2003). In addition, the involvement of top management in strategic planning makes it effective. The manager's participation ensured that strategic planning matches the style of top management (Obeng and Ugboro 2008). It appears that different studies suggest that participation by middle managers leads to better strategic plan formulation and the facilitation of their implementation (Hirschman 1970, Bourgeois and Brodwin 1984) and a reduction in behavioural impediments to the effectiveness of strategic planning (Lyles and Lenz 1982, Hart 1992, Elbanna 2008). 
As for competitive strategies, identifying an organization's competitive position is important to the selection of competitive marketing strategies (McDonald 1996). There is a link between competitive advantage and marketing strategy, the purpose of the competitive advantage is to identify an essential and sustainable basis from which to compete, while the aim of the marketing strategy is to deliver this advantage to the market place (Drummond al. 2010). In addition, competitive advantage is developed at the SBU. It involves four main dimensions: determination of mission statement, evaluation and selecting of generic strategies, objective setting and policy making. Marketing strategy is developed in the marketing department. It involves three dimensions: choosing the target market, assessing the competitors' strategies, and designing the marketing mix strategies (West et al. 2010).

\section{Design/Methodology/Approach}

According to Falshaw et al. (2006), most studies in strategic planning were found in developed countries, yet little is known about this issue in developing countries such as Libya. This study focuses on the SMP being used by the main state LCBs (the Gumhouria Bank, the Sahara Bank, the Wahda Bank and the National Commercial Bank). Due to insufficient data available in the LCBs about SMP, the current article applies an exploratory research design. An interpretive philosophy was seen to give an enriched understanding of the empirical situation.

It builds on a combination of qualitative and quantitative methods in order to achieve a full investigation into this issue. Creswell (2013), suggested that triangulation is the easiest way of establishing validity. Because of the fact that there is an insufficient knowledge of the phenomena, the findings are not representative of the whole population. The target population in this study will be Libyan banks.

In order to enhance the confident of a researcher's perceptions and to establish credibility of the research findings the researcher is also used other methods, for example: member-checking, rich description, clarification of biases and reporting of discrepant information.

The qualitative approach was achieved using semi-structured interviews with eight managers, two interviews per each bank. These interviewees were chosen directly from the websites of these banks. They were working in these banks between 16 of July and 7 of October 2009 (Director of Marketing, Director of Retail, Director of Operations, Director of the branches). The interview is based on themes which are arrived at through reviewing the literature. Being interpretive, the analysis leans heavily on the content. Therefore, pattern matching and coding analysis was used as an appropriate approach in meeting the specific research objectives.

To enrich the breadth and depth of the findings, the quantitative approach has been used through a semi-structured questionnaire survey. The total number of respondents is forty one. They were chosen purposively by their job 
title. The descriptive statistic analysis was used to analyze the questionnaires. Close-ended questions constructed on a five point rating Likert scale format were used, and SPSS for windows version 21 was utilised for data analysis. The final survey instrument consisted of only one main questionnaire with approximately 111 questions. A reliability mean and standard deviation were used for each specific item.

The archival approach was also used to collect the required data. This research was carried out prior to the events in Libya in February 2011.

\section{Results and Discussion}

The findings reveal that, before 2007, LCBs did not follow any type of SMP process. The key drivers for introducing SMP into the field of the banking industry seem to be more externally driven, particularly by the demands of the market, customers and changes in marketing practices (Table 1, Items $1,2,3 \& 4)$.

SMP facilities have yet to be introduced into LCBs (Table 1, Item 5). These facilities have been used in various Arab countries with varied degrees of success. Khan and Ali-Buarki (1992) studied ten of the most common SMP tools in Bahrain, and found that planners had a very limited understanding of the use of strategic concepts and planning, a result similar to the current study's findings.

The Central Bank of Libya hired the Mckinsey Company to help the LCBs in the process of strategic planning (Table 1, Item 6). This is consistent with Calantone et al. (2003) who stated that organizations can use an external facilitator if their SMP experience is low or there are insufficient facilitation skills. However, it is inconsistent with some Arab organizations practice. For example, Al-Shammari and Hussein (2008) found that Jordanian Manufacturing Organisations rarely rely on external consultants for their planning activities.

Since 2007, LCBs have formed committees consisting of the topmanagement levels of the banks in charge of SMP (Table 2, Item 1). This action is consistent with the findings of Calantone et al. (2003) and Efendioglu and Karabulut (2010). This action is also similar to the Greek management policy, which involves only top management in the process of strategic planning (Koufopoulos and Chryssochoidis 2000).

Before 2007, marketing activities were distributed amongst the departments in the banks in the way outlined by Piercy (1985), Hooley et al. (1990), Varadarajan (1992), Thwaites and Lynch (1992) and Workman et al. (1998). However, in 2007, in order to achieve competitive advantage, marketing departments were established, as suggested by Day (1994) and Song et al. (2008).

The current study has found that a few of the LCBs have recently realized the importance of marketing departments and concentrated on training employees, in order to contribute to the process of banking and financial 
renovation and development, to discover investment opportunities, to study new projects, and to keep abreast of the situation of the bank's competitors.

Table 1. The key Drivers for Introducing SMP into the LCBS

\begin{tabular}{|c|c|c|c|c|c|c|c|c|c|c|c|c|c|}
\hline \multirow{2}{*}{ STA } & \multicolumn{2}{|c|}{ S. DIS } & \multicolumn{2}{|c|}{ DIS } & \multicolumn{2}{|l|}{ UN } & \multicolumn{2}{|l|}{ AG } & \multicolumn{2}{|c|}{ S. AG } & \multirow{2}{*}{ STD } & \multirow{2}{*}{$\mathbf{M}$} & \multirow{2}{*}{ PC } \\
\hline & PE (\%) & FR & PE (\%) & FR & PE (\%) & FR & PE (\%) & FR & PE (\%) & FR & & & \\
\hline 1 & - & - & 31 & 13 & 23.8 & 10 & 42.9 & 18 & 2.4 & 1 & 1.04 & 3.10 & .674* \\
\hline 2 & 14.3 & 4 & 31 & 13 & 33.4 & 14 & 16.7 & 7 & 4.8 & 2 & 1.09 & 2.66 & $0.366^{*}$ \\
\hline 3 & 4.8 & 2 & 26.2 & 11 & 23.8 & 10 & 31 & 13 & 14.3 & 6 & 1.16 & 3.24 & $0.573^{*}$ \\
\hline 4 & 2.4 & 1 & 31 & 13 & 19.1 & 8 & 40.5 & 17 & 7.1 & 3 & 1.27 & 3.05 & 0.361 \\
\hline 5 & 2.4 & 1 & 14.3 & 6 & 19.1 & 8 & 54.8 & 23 & 9.5 & 4 & 0.95 & 3.56 & 0.368 \\
\hline 6 & 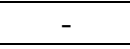 & - & 4.8 & 2 & 7.2 & 3 & 28.6 & 12 & 59.5 & 25 & 0.81 & 4.46 & - \\
\hline 7 & - & - & 38.1 & 16 & 14.3 & 6 & 38.1 & 16 & 7.1 & 3 & 1.15 & 3.07 & 0.451 \\
\hline 8 & - & - & 7.6 & 20 & 31 & 13 & 19 & 8 & - & - & 0.89 & 2.63 & $591 *$ \\
\hline 9 & 47.6 & 20 & 28.6 & 12 & 7.2 & 3 & 16.7 & 7 & - & - & 1.14 & 1.83 & - \\
\hline 10 & & 2 & .3 & 6 & 23.8 & 10 & 28.6 & 12 & 28.6 & 12 & 1.20 & 3.63 & - \\
\hline 11 & 9.5 & 4 & 21.4 & 9 & 31 & 13 & 28.6 & 12 & 9.5 & 4 & 1.15 & 3.07 & 0.656 \\
\hline 12 & - & - & - & - & - & - & - & - & 40.5 & 17 & 0.75 & 4.20 & 0.454 \\
\hline
\end{tabular}

Key Table:

STA $\rightarrow$ Statement; S. DIS $\rightarrow$ Strongly Disagree; DIS $\rightarrow$ Disagree; UN $\rightarrow$ Undecided; AG $\rightarrow$ Tend to Agree; S. AG $\rightarrow$ Strongly Agree; STD $\rightarrow$ Standard Deviation; $\mathbf{M} \rightarrow$ Mean; PE $\rightarrow$ Percentage; FR $\rightarrow$ Frequency.

Person Correlation between SMP and these items is: ** highly significant at $0.01 ; *$ significant at 0.01 .

1 In our industry, demand was unpredictable.

2 Declining markets for services have been a major challenge in our industry.

3 Our bank has to change its marketing practices frequently.

4 In our bank, the modes of services have changed often and in many ways.

5 The bank uses a number of tools to encourage good planning.

6 The bank uses external sources (e.g. consultants, agencies) for new ideas.

7 CEOs and staff planners are responsible for the SMP function.

8 The planning department is responsible for the SMP function.

9 Employees are allowed to make any decisions without checking with anybody else.

10 Any major decisions that employees make must have the approval of top managers.

11 The bank encourages participative decision-making processes in and between different organisational levels.

12 Non-financial and financial measures are equally important.

The majority of the managers interviewed were aware that a great many staff in the sales and marketing departments were highly qualified graduates, but, none of them had a professional marketing qualification, and most of them were not trained in marketing (Table 2, Item 2)

LCBs have developed their own comprehensive plans with flexible practices, i.e. SMP is in its infancy (Table 2, Items $3 \& 4$ ), and so implementation barriers are to be expected. Regarding SMP, the barriers, for example, are: lack of experience in marketing research; a lack of involvement by marketing managers (Table 2, Items $5 \& 6$ ); a lack of reliable, accurate, relevant and valid information; difficulty in anticipating changes in the business environment; a lack of required capability to implement the SMP (Table 1, Items $7 \& 8$ ) and achieve the banks goals; an absence of an accurate database; and fluctuating demand and supply of liquidity. 
Table 2. SMP Committees and Participating in the Process of the LCBS

\begin{tabular}{|c|c|c|c|c|c|c|c|c|c|}
\hline \multirow{2}{*}{ QUE } & \multicolumn{2}{|c|}{ NO. A } & \multicolumn{2}{|c|}{ Yes } & \multicolumn{2}{|c|}{ No } & \multirow{2}{*}{ STD } & \multirow{2}{*}{ PC } \\
\cline { 2 - 10 } & PE (\%) & FR & PE (\%) & FR & PE (\%) & FR & & & \\
\hline 1 & 4.8 & 2 & 40.5 & 17 & 54.8 & 23 & 0.55 & 1.59 & $0.509^{* *}$ \\
\hline 2 & 35.7 & 15 & 59.5 & 25 & 1 & 35.7 & 0.55 & 1.54 & $0.382^{*}$ \\
\hline 3 & 9.5 & 4 & 81 & 34 & 9.5 & 4 & 0.42 & 1.02 & $0.487^{* *}$ \\
\hline 4 & 9.5 & 4 & 57.1 & 24 & 33.3 & 14 & 0.60 & 1.27 & $0.539^{* *}$ \\
\hline 5 & 21.4 & 9 & 35.7 & 15 & 42.9 & 18 & 0.77 & 1.24 & $0.591^{* *}$ \\
\hline 6 & 9.5 & 4 & 31 & 13 & 59.5 & 25 & 0.50 & 1.27 & $0.471^{* *}$ \\
\hline
\end{tabular}

Key Table:

QUE $\rightarrow$ Question; NOA $\rightarrow$ No Answer; PE $\rightarrow$ Percentage; FR $\rightarrow$ Frequency.

Person Correlation between SMP and these items is: ** highly significant at 0.01 ; * significant at 0.01 .

1. Is there a SMP commission/committee in your bank?

2. Have you ever got training in marketing?

3. Does your bank prepare written strategic plans?

4. Does your bank prepare written strategic marketing plans?

5. Does this commission have access to senior management?

6. Do you ever participate in strategic plan formulation?

In relation to "Organizational Configuration", this study has found a block to information and decision-making participation between the "layers" of the organization's managers; this could reduce the effectiveness of the SMP approach (Table 1, Items 9, 10 \& 11).

There are several factors influencing LCB's ability to implement SMP's process, for example, sources of information, the process of decision-making, relations between superiors and subordinates, functional competences and the work systems, marketing managers' abilities and the relationship between the LCBs and their customers.

Regarding the usage of information, in order to prepare periodical reports, measure the banks performance, detect problems and look for solutions, make prudent decisions., formulate and develops the banks strategies, the LCBs used two sources of information, internally and externally (Table 3 , Item 1).

Concerning relations between superiors and subordinates, the current research found the work environment within LCBs is characterized by friendliness and mutual respect. A good relationship between middle and senior managers enables middle managers to incorporate their ideas into the organization's personal strategy (Hoon 2007).

The banking work in the LCBs used to be conducted manually. Recently, in order to facilitate the work, save time and effort, and improve overall performance, LCBs have introduced new work systems (NPS and SWIFT), and have followed up with an intensive training programme to go with the new systems and with new functions. Training programs differ from one bank to another; some are keen to identify basic training needs for the new employees in order to help them to understand and accomplish their work. Special sessions are also required in special situations, e.g. for the NPS. However, it was found that training in marketing is not a major priority (Table 2, Item 2). 
Considering the managers abilities, it was found that LCBs marketing managers do not have the required abilities to develop the banks' future strategies and specifically their marketing strategies (Table 1, Items $7 \& 8$ ). This can negatively affect the relationship with those who deal with the banks, because, for example, they do not have the required abilities to understand the customers' needs in order to satisfy them, as a result, they cannot fully integrate their relationship (Vrontis et al. 2006). Therefore, improving their abilities is necessary.

LCBs use different motivations or values to inspire people to purchase their services (Table 3, Items $2 \& 3$ ). For example, service quality (Rice et al. 1990, Wille 1992, Voss et al. 2005) speed of delivery, ease of procedures, the banks' reputation (Anderson et al. 1994), and offering easy access to banking services are the most common policies to attract customers, and depending on the strategic foreign partner to provide better services.

Table 3. Type of Collected Data

\begin{tabular}{|c|c|c|c|c|c|c|c|c|c|c|c|c|c|}
\hline \multirow{2}{*}{ STA } & \multicolumn{2}{|c|}{ ANEV } & \multicolumn{2}{|c|}{ NVO } & \multicolumn{2}{|c|}{ SOM } & \multicolumn{2}{|c|}{ OFT } & \multicolumn{2}{|l|}{$\mathbf{A A}$} & \multirow{2}{*}{ STD } & \multirow{2}{*}{ M } & \multirow{2}{*}{ PC } \\
\hline & PE (\%) & FR & PE (\%) & FR & PE (\%) & FR & PE (\%) & FR & PE (\%) & FR & & & \\
\hline 1 & 9.5 & 4 & 16.7 & 7 & 23.8 & 10 & 28.6 & 12 & 11.9 & 5 & 0.64 & 1.54 & $0.494 * *$ \\
\hline 2 & 4.8 & 2 & 4.8 & 2 & 9.5 & 4 & 42.9 & 18 & 38.1 & 16 & \begin{tabular}{|l|}
0.954 \\
\end{tabular} & 4.12 & - \\
\hline 3 & 2.4 & 1 & 2.4 & 1 & 2.4 & 1 & 42.9 & 18 & 50 & 21 & 0.673 & 4.44 & $0.665^{* *}$ \\
\hline \multicolumn{14}{|c|}{$\begin{array}{l}\text { STA } \rightarrow \text { Statement; ANEV } \rightarrow \text { Almost Never; NVO } \rightarrow \text { Not Very Often; SOM } \rightarrow \text { Sometimes; } \\
\text { OFT } \rightarrow \text { Often; AA } \rightarrow \text { Almost Always; STD } \rightarrow \text { Standard Deviation; MEA } \rightarrow \text { Mean; PE } \rightarrow \\
\text { Percentage; FR } \rightarrow \text { Frequency. } \\
\text { Person Correlation between SMP and these items is: } * * \text { highly significant at } 0.01 ; * \text { significant } \\
\text { at } 0.01 .\end{array}$} \\
\hline
\end{tabular}

LCBs measure their performance financially and non-financially. This measure is supported by Clark (1999) and Rust et al. (2004). Financial measures and non-financial measures are equally important to LCBs. The most common financial measures used by the LCBs are balance sheets, income statements and cash flows, then market share and ROA. The most important non-financial indicators for the LCBs are a good reputation, customer complaints, training and development, rate of absenteeism and the number of new accounts opened.

With regard to the future of the Libyan banking industry, several factors have been identified which could possibly affect this industry in the future; for example, technology (which offers customers a huge amount of modern financial services) (Dickson 1992, Kashani 1996), the opening of the Libyan market to the world, changes in economic conditions (the financial crises and the factors of instability) (Wilson and Gilligan 1997), and the configuration of political, social and demographic aspects of society.

As a result, although economic openness has a positive impact on the economy, LCBs are facing the danger of competition from foreign banks, 
because these are strong financially and non-financially (Kashani 1996, Wilson and Gilligan 1997).

\section{Conclusions}

\section{The Major Findings}

Comprehensive strategic plans are in place, but that the processes by which they are created have significant limitations. In addition, SMP in the LCBs is still evolving and that it is, currently, in growth. In terms of marketing lifecycle, marketing in LCBs is was found in its infancy stage, contrary to expectations that marketing departments have only been established recently. For this reason a number of barriers to SMP were found.

\section{The Main Contributions}

Understanding the process of SMP that is being introduced into LCBs; determining the contextual factors that affect the implementation of SMP; identifying the major barriers to the success of the implementation of SMP and providing a practical framework for SMP in the LCBs in order to enhance its success.

\section{Managerial Implication}

The key implications of the study for improving the current implementation of SMP in the LCBs are summarized in the following actions:

The study has examined the SMP practice of the LCBs and provided a detailed description of LCBs goals and strategies, the Libyan business environment and some of the Libyan management styles. Therefore, this information can help Libyan managers in this industry to identify the critical factors that can affect their success. Based on an understanding of what others did in terms of their business practice, LCBs which are already implementing SMP may use this information for developing their strategies, and they will roll out SMP to the other banks in the field.

It should be noted, however, that establishing marketing departments is very important to success in a competitive environment. Success requires more effort and takes longer, therefore, when they delegate more authority to marketing managers their opinions and decisions would become achievable, effective and more acceptable to others.

The study provides some insights for the LCBs' top management who are interested in improving SMP. Employing specialists in marketing departments and training the current staff enables LCBs to complete what the Mckinsey Company started doing and enables the staff to develop the current strategy without help from anybody. 
Care should be given to the type of organizational culture and behaviour when formulating and implementing SMP, because successful strategies will not be achieved if planners do not consider the cultural issues.

\section{Limitations of the Study}

This research did not examine the situation within all LCBs. It studied only four LCBs that were expected to have standard SMP practices, heavily influenced by senior management. In addition, because of the researcher's time and information resource constraints.

Libya suffers from a problem of a lack of published data, and this has prevented comparisons between the findings of the current research and other research in Libya. Furthermore, because there is no longitudinal data ready to use, the correlation between SMP and the LCBs' performance could not be done. However, similar situations (strategic planning) have been examined in some other Arab countries and a comparison with these studies was drawn.

\section{References}

Akroush MNA (2003) An integrated approach to marketing strategy formulation and implementation. University of Huddersfield.

Al-Shammari HA, Hussein RT (2007) Strategic planning-firm performance linkage: empirical investigation from an emergent market perspective. Advances in Competitiveness Research 15(1-2): 15.

Al-Shammari HA, Hussein RT (2008) Strategic planning in emergent market organizations: empirical investigation. International Journal of Commerce and Management 18(1): 47-59.

Anderson EW, Fornell C, Lehmann DR (1994) Customer satisfaction, market share, and profitability: findings from Sweden. The Journal of Marketing 58(3): 53-66.

Anderson PF (1982). Marketing, strategic planning and the theory of the firm. The Journal of Marketing 46(2): 15-26.

Ansoff HI (1991) Critique of Henry Mintzberg's "The design school: reconsidering the basic premises of strategic management". Strategic Management Journal 12(6): 449-461.

Baker MJ (2007). Marketing Strategy and Management: Second Edition. Palgrave Macmillan.

Bourgeois LJ, Brodwin DR (1984) Strategic implementation: Five approaches to an elusive phenomenon. Strategic Management Journal 5(3): 241-264.

Bradmore D (1996) Competitive Advantage: Concepts \& Cases. Prentice Hall.

Brooksbank R (1999) The theory and practice of marketing planning in the smaller business. Marketing Intelligence \& Planning 17(2): 78-91.

Calantone R, Garcia R, Dröge C (2003) The effects of environmental turbulence on new product development strategy planning. Journal of Product Innovation Management 20(2): 90-103.

Clark BH (1999) Marketing performance measures: history and interrelationships. Journal of Marketing Management 15(8): 711-732. 
Claycomb C, Germain R, Dröge C (2000) The effects of formal strategic marketing planning on the industrial firm's configuration, structure, exchange patterns, and performance. Industrial Marketing Management 29(3): 219-234.

Coulthard M, Howell A, Clarke G (1996) Business Planning: The Key to Success. Macmillan Education Australia.

Creswell JW (2013) Research Design: Qualitative, Quantitative, and Mixed Methods Approaches. Sage.

Day GS (1994) The capabilities of market-driven organizations. The Journal of Marketing 58(4): 37-52.

Dibb S, Farhangmehr M, Simkin L (2001) The marketing planning experience: a UK and Portuguese comparison. Marketing Intelligence \& Planning 19(6): 409-417.

Dickson PR (1992) Toward a general theory of competitive rationality. The Journal of Marketing 56(1): 69-83.

Drummond G, Ensor J, Ashford R (2010) Strategic Marketing. Routledge.

Efendioglu AM, Karabulut T (2010) Impact of strategic planning on financial performance of companies in Turkey. International Journal of Business and Management 5(4): P3.

Elbanna S (2008) Planning and participation as determinants of strategic planning effectiveness: evidence from the Arabic context. Management Decision 46(5): 779-796.

Falshaw JR, Glaister KW, Tatoglu E (2006) Evidence on formal strategic planning and company performance. Management Decision 44(1): 9-30.

Hart SL (1992) An integrative framework for strategy-making processes. Academy of Management Review 17(2): 327-351.

Hirschman AO (1970) Exit, Voice, and Loyalty: Responses to Decline in Firms, Organizations, and States. Harvard University Press.

Homburg C, Workman JP, Jensen O (2000) Fundamental changes in marketing organization: the movement toward a customer-focused organizational structure. Journal of the Academy of Marketing Science 28(4): 459-478.

Hooley GJ, Lynch JE, Shepherd J (1990) The marketing concept: putting the theory into practice. European Journal of Marketing 24(9): 7-24.

Hoon C (2007) Committees as strategic practice: The role of strategic conversation in a public administration. Human Relations 60(6): 921-952.

Hussey DE (1985) Introducing Corporate Planning. Pergamon Press.

Kashani K (1996) A New Future for Brands. Financial Times, Mastering Management.

Khan GM, Ali-Buarki E (1992) Strategic planning in Bahrain. Management Decision $30(5)$.

Koufopoulos DN, Chryssochoidis GM (2000) The effects of an uncertain country environment upon leadership and strategic planning practices. Strategic Change 9(6): 379-395.

Lyles MA, Lenz R (1982) Managing the planning process: A field study of the human side of planning. Strategic Management Journal 3(2): 105-118.

McDaniel SW, Kolari JW (1987) Marketing strategy implications of the Miles and Snow strategic typology. The Journal of Marketing 51(4): 19-30.

McDonald M (1996) Strategic marketing planning: theory, practice and research agendas. Journal of Marketing Management 12(1-3): 4-27.

McDonald M (2007). Malcolm Mcdonald on Marketing Planning: Understanding Marketing Plans and Strategy. Kogan Page Publishers.

McDonald MH (1989) Ten barriers to marketing planning. Journal of Marketing Management 5(1): 1-18. 
McGivern Y (2009) The Practice of Market Research: An Introduction. Pearson Education.

Miller D, Friesen PH (1983) Strategy-making and environment: The third link. Strategic Management Journal 4(3): 221-235.

Moore JI (2001) Writers on Strategy and Strategic Management: Theory and Practice at Enterprise, Corporate, Business and Functional Levels. Penguin UK.

Moorman C, Rust RT (1999) The role of marketing. The Journal of Marketing 63: 180-197.

O'Shaughnessy J (1995) Competitive Marketing: A Strategic Approach. Routledge.

Obeng K, Ugboro I (2008) Effective strategic planning in public transit systems. Transportation Research Part E: Logistics and Transportation Review 44(3): 420-439.

Olson EM, Slater SF, Hult GTM (2005) The performance implications of fit among business strategy, marketing organization structure, and strategic behavior. Journal of Marketing 69(3): 49-65.

Piercy N (1985) Marketing Organisation: An Analysis of Information Processing, Power, and Politics. Allen \& Unwin.

Rice RW, Phillips SM, McFarlin DB (1990) Multiple discrepancies and pay satisfaction. Journal of Applied Psychology 75(4): 386.

Rust RT, Ambler T, Carpenter GS, Kumar V, Srivastava RK (2004) Measuring marketing productivity: current knowledge and future directions. Journal of Marketing 68(4): 76-89.

Song M, Nason RW, Di Benedetto CA (2008) Distinctive marketing and information technology capabilities and strategic types: A cross-national investigation. Journal of International Marketing 16(1): 4-38.

Thwaites D, Lynch JE (1992) Adoption of the marketing concept by UK building socities. Service Industries Journal 12(4): 437-462.

Varadarajan PR (1992) Marketing's contribution to strategy: the view from a different looking glass. Journal of the Academy of Marketing Science 20(4): 335-343.

Voss C, Tsikriktsis N, Funk B, Yarrow D, Owen J (2005) Managerial choice and performance in service management-a comparison of private sector organizations with further education colleges. Journal of Operations Management 23(2): 179195.

Vrontis D, Kogetsidis H, Stavrou A (2006) Strategic marketing planning for a supplier of liquid food packaging products in Cyprus. Journal of Business \& Industrial Marketing 21(4): 250-261.

West D, Ford J, Ibrahim E (2010) Strategic Marketing: Creating Competitive Advantage. Oxford University Press.

Wille E (1992) Quality: Achieving Excellence. Century Business.

Wilson R, Gilligan C (1997) Strategic marketing management: planning, implementation and control. The Chartered Institute of Marketing/ButterworthHeinemann Marketing Series.

Workman Jr. JP, Homburg C, Gruner K (1998) Marketing organization: an integrative framework of dimensions and determinants. The Journal of Marketing 62: 21-41. 
